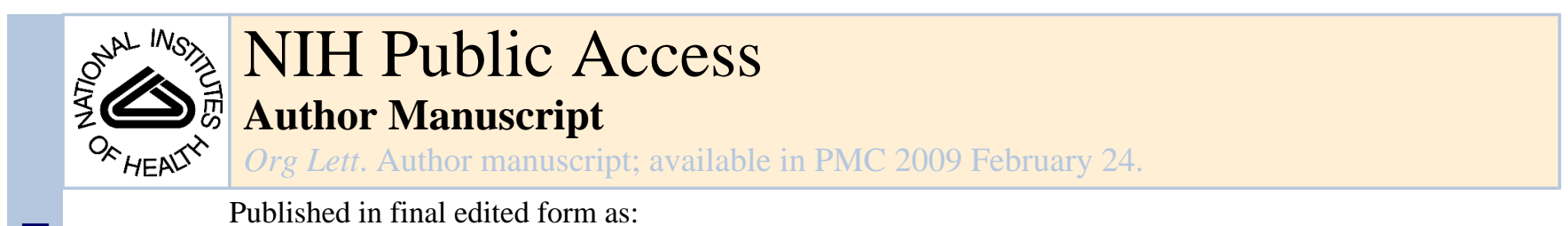

Published in final edited form as:

Org Lett. 2006 September 28; 8(20): 4541-4543. doi:10.1021/ol061736p.

\title{
Practical Total Syntheses of Epiquinamide Enantiomers
}

\author{
Takashi L. Suyama and William H. Gerwick \\ University of California, San Diego, Scripps Institution of Oceanography, 9500 Gilman Drive MC \\ 0212, La Jolla, CA 92093, USA
}

\section{Abstract}

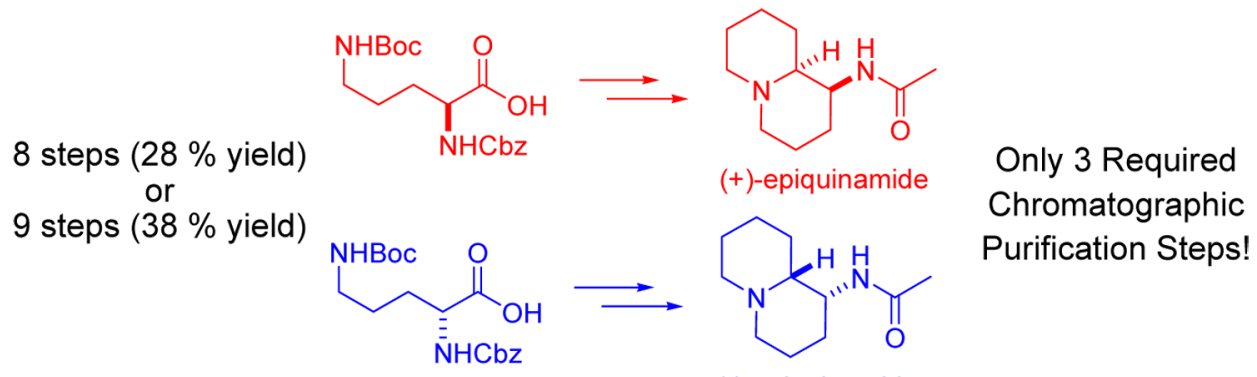

Short and practical syntheses of epiquinamide and its enantiomer were accomplished with high overall yields and high stereoselectivity from readily available starting materials.

Rainforest frogs have been a rich source of neurologically relevant alkaloids. ${ }^{1-3}$ Epibatidine 1 was isolated from an Ecuadorian frog Epipedobates tricolor in 1992 by Daly and coworkers and has become one of the cornerstone compounds in the field of nicotinic acetylcholine receptor (nAChR) studies. ${ }^{3,4}$ Epiquinamide $\mathbf{2}$ was isolated along with $\mathbf{1}$ from the same frog species in $2003,{ }^{1}$ and has attracted much attention due to its potent and selective agonistic activities against $\beta 2$ nicotinic receptors. ${ }^{1,3}$ Its potential to be a lead compound in the development of pharmacological agents seems promising, following the history of epibatidine. 2,4 The varying abundance of nAChRs subtypes in different tissues should enable their selective therapeutic targeting. ${ }^{5-7}$ However, the major limiting factor in testing this compound has been its low availability ( $240 \mu \mathrm{g}$ from the skins of 183 frogs). ${ }^{1}$ To date, two total syntheses of (+)-epiquinamide 8,9 , another synthesis of the antipode, ${ }^{10}$ and a racemic synthesis ${ }^{11}$ have been reported. However, these enantiospecific syntheses are relatively long $\left(12,814,{ }^{9}\right.$ and 13 steps ${ }^{10}$ respectively) and/or their starting materials are either highly expensive or not readily available. We therefore undertook the development of a practical and flexible synthesis that could provide substantial amounts of 2 .

In the literature on epiquinamide, the optical rotation value of the natural product was never reported due to its low availability. ${ }^{1}$ Access to both enantiomers is therefore of great importance. Herein described is the synthesis of epiquinamide and its enantiomer.

The quinolizidine ring could be derived from a piperidine with appropriate appendages that could be cyclized to give the second ring. Initially, we were interested in developing a reductive amination-type method for the construction of the first ring since there has been little effort to synthesize cis 2,3-disubstituted piperidines via such an approach. ${ }^{12}$ This approach, however,

wgerwick@ucsd.edu. 
was not fruitful in our hands; the reductive amination cyclization yielded trans piperidine $\mathbf{1 0}$ in excellent de. The relative stereochemistry of this product was determined by X-ray crystallography after it was converted to the Cbz-protected quinolizidine (11). ${ }^{13}$

We then envisioned a dissection of the molecule in a similar manner to the first attempt, but differing in the mode of first cyclization. The intramolecular $\mathrm{S}_{\mathrm{N}} 2$ cyclization would yield the 2,3-disubstituted piperidine $\mathbf{3}$ with the inverted stereochemistry. The substrate for the $\mathrm{S}_{\mathrm{N}} 2$ reaction can be easily derived from a corresponding amino alcohol, such as $\mathbf{8}$, which could be synthesized from ornithine. The synthesis of the intramolecular $\mathrm{S}_{\mathrm{N}} 2$ substrate began with a commercially available ornithine derivative $\mathbf{5}$, which was first converted smoothly to the Weinreb amide 6 using a common coupling condition. ${ }^{14}$ After simple washings, the product was fairly pure and required no further purification. Upon treatment with allyl Grignard reagent, we obtained the ketone 7 as white crystals. Chelation-controlled hydride reduction of 7 yielded a highly crystalline alcohol, $8 .{ }^{15} \mathrm{By}{ }^{1} \mathrm{H}$ and ${ }^{13} \mathrm{C} \mathrm{NMR}$, none of the other diastereomer was observed in the crystallized product, whose stereochemistry was ultimately proven by completion of the total synthesis and comparison to epi-epiquinamide (12) ${ }^{16}$ Mesylation of the amino alcohol proceeded smoothly with an excellent yield, and again the product was crystalline. Therefore, the synthesis of the $S_{N} 2$ substrate 4 was accomplished very conveniently and without chromatographic purification unless recovery of the residual amount of the product in the filtrate was desired.

Transformation of the mesylate $\mathbf{4}$ to the title compound was accomplished as shown in scheme 3. Removal of the Boc group in TFA / $\mathrm{CH}_{2} \mathrm{Cl}_{2}$ followed by intramolecular $\mathrm{S}_{\mathrm{N}} 2$ cyclization induced by $\mathrm{K}_{2} \mathrm{CO}_{3}$ and subsequent $\mathrm{N}$-alkylation in acetonitrile yielded the di-allyl piperidine 3 in good yield (9 was not isolated or characterized). ${ }^{17-19}$ The synthesis of the epiquinamide skeleton was concluded by ring closing metathesis (RCM) reaction on $\mathbf{3}$ using Grubbs second generation catalyst. ${ }^{20}$ It is noteworthy that this is one of the first examples of a basic $\mathrm{N}$-allyl group undergoing ruthenium catalyzed RCM. ${ }^{21}$ The scope of functional group tolerance by Grubbs second generation catalyst may be even greater than the current concensus. $20 \mathrm{~b}, 22$ However, the purification of this rather polar RCM product presented difficulties. ${ }^{23}$ The problem was overcome when Cho and Kim's method was employed with a small modification. 24 Deprotection, alkene reduction, and acetylation were accomplished in one-pot by hydrogenation of 10 in ethanol with acetic anhydride. ${ }^{25} \mathrm{~A}$ better yield was observed when this process was separated into 2 steps as shown in scheme $3 .{ }^{10} \mathrm{By}{ }^{1} \mathrm{H}$ and ${ }^{13} \mathrm{C}$ NMR, a single isomer was observed. The reproducible overall yields of $\mathbf{2}$ beginning from $\mathbf{5}$ were $38 \%$ and $28 \%$ for the longer and shorter sequences respectively $\left((+)-2[\alpha]_{\mathrm{D}}{ }^{22}=+24^{\circ}, c 0.10, \mathrm{CHCl}_{3}\right)$. 26 Only three chromatographic purification steps were required throughout the synthesis.

The synthesis of the other enantiomer was performed in the same manner starting with commercially available $\delta N$-Boc- $\alpha N$-Cbz-D-ornithine. This latter synthesis was accomplished in two weeks, demonstrating the practicality of this synthetic route $\left((-)-2[\alpha]_{\mathrm{D}}{ }^{22}=-22^{\circ}, c\right.$ $\left.0.13, \mathrm{CHCl}_{3}\right) .{ }^{27}$

Since neither the optical rotation value nor the circular dichroism spectrum of the authentic natural product were reported, the absolute stereochemistry of the natural product could not be determined despite our access to both enantiomers. We then sought to learn the biological properties of the two isomers. However, contrary to our expectation, neither of the enantiomers showed activity in our routine $\mathrm{Na}^{+}$channel blocking / activation assays, $\mathrm{H} 460$ cancer cytotoxicity assay, or brine shrimp toxicity assay. Our results are consistent with a recent report for synthetic ( \pm )-epiquinamide which was inactive in competitive binding assays using $\left[{ }^{3} \mathrm{H}\right]$ epibatidine, and thus makes further uncertain the identity of the pharmacologically active material from the frogs. ${ }^{11}$ 


\section{Supplementary Material}

Refer to Web version on PubMed Central for supplementary material.

\section{Acknowledgment}

The NIH (NS053398) is thanked for their financial support for this research. We wish to thank Mr. Joshua Wingerd at UCSD for $\mathrm{Na}^{+}$channel and cytotoxicity assays. The Department of Chemistry at UCSD and Prof. Emmanuel Theodorakis at UCSD are thanked for the use of IR and polarimeter respectively.

\section{References}

1. Fitch RW, Garrafo HM, Spande TF, Yeh HJC, Daly JW. J. Nat. Prod 2003;66:1345-1350. [PubMed: 14575435]

2. Baker DD, Alvi KA. Curr. Opin. Biotechnol 2004;15:576-583. [PubMed: 15560985]

3. (a) Daly JW. Cell. Mol. Neurbiol 2005;25:513-552. (b) Daly JW, Spande TF, Garrafo HM. J. Nat. Prod 2005;68:1556-1575. [PubMed: 16252926]

4. Spande TF, Garrafo HM, Edwards MW, Yeh HJC, Pannell L, Daly JW. J. Am. Chem. Soc 1992;114:3475-3478.

5. Vincler M. Expert Opin. Investig. Drugs 2005;14:1191-1198.

6. Anthenelli RM. Clin. Neurosci. Res 2005;5:175-183.

7. Gotti C, Riganti L, Vailati S, Clementi F. Curr. Pharm. Design 2006;12:407-428.

8. Tong SK, Barker D. Tetrahedron Lett 2006;47:5017-5020.

9. Huang PQ, Guo ZQ, Ruan YP. Org. Lett 2006;8:1435-1438. [PubMed: 16562910]

10. Wijdeven MA, Botman PNM, Wijtmans R, Schoemaker HE, Rutjes FPJT, Blaauw RH. Org. Lett 2005;7:4005-4007. [PubMed: 16119953]

11. Kanakubo A, Gray D, Innocent N, Wonnacott S, Gallagher T. Bioorg. Med. Chem. Lett 2006;16:4648-4651. [PubMed: 16784846]

12. a) Pal K, Behnke ML, Tong L. Tetrahedron Lett 1993;34:6205-6208. b) Singh R, Ghosh SK. Tetrahedron Lett 2002;43:7711-7715. c) Gómez-Monterrey I, González-Muñiz R, Herranz R, García-López MT. Tetrahedron Lett 1993;34:3593-3594. d) Jefford CW, Wang JB. Tetrahedron Lett 1993;34:2911-2914.

13. An initial attempt to asymmetrically synthesize the title compound was made.

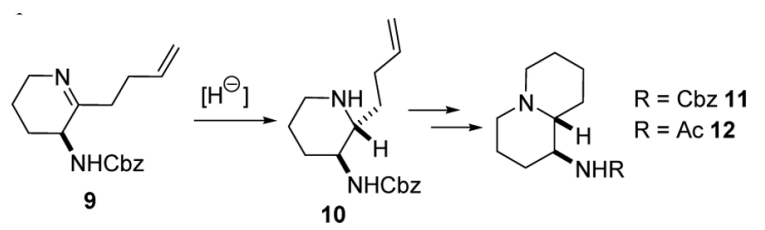

14. a) Nahm S, Weinreb SM. Tetrahedron Lett 1981;22:3815-3818. b) Mentzel M, Hoffmann HMR. J. Prakt. Chem./ Chem.-Ztg 1997;339:517-524.

15. a) So RC, Ndonye R, Izmirian DP, Richardson SK, Guerrera RL, Howell AR. J. Org. Chem 2004;69:3233-3235. [PubMed: 15104474] b) Haug BE, Rich DH. Org. Lett 2004;6:4783-4786. [PubMed: 15575685] 
16. The bridgehead proton of $\mathbf{2}$ has a chemical shift of $\delta 3.91 \mathrm{ppm}$ and while that of $\mathbf{1 2}$ has a shift of $\delta$ $3.95 \mathrm{ppm}$ in $\mathrm{MeOH}-\mathrm{d} 4$. Otherwise the two compounds have exactly the same carbon framework and molecular weight by NMR and LRMS.

17. a) Abe H, Aoyagi S, Kibayashi C. J. Am. Chem. Soc 2005;127:1473-1480. [PubMed: 15686380] b) Wang Q, Sasaki NA. J. Org. Chem 2004;69:4767-4773. [PubMed: 15230600]

18. Cyclization was extremely slow in the absence of base.

19. a) Sundberg RJ, Amat M, Fernando AM. J. Org. Chem 1987;52:3151-3159. b) Kinderman SS, Wekking MMT, van Maarseveen JH, Schoemaker HE, Hiemstra H, Rutjes FPJT. J. Org. Chem 2005;70:5519-5527. [PubMed: 15989333]

20. a) Scholl M, Ding S, Lee CW, Grubbs RH. Org. Lett 1999;1:953-956. [PubMed: 10823227] b) Nicolaou KC, Bulger PG, Sarlah D. Angew. Chem. Int. Ed 2005;44:4490-4527.

21. To our knowledge, one such example was accomplished recently with a water-soluble ruthenium catalyst. See Hong SH, Grubbs RH. J. Am. Chem. Soc 2006;128:3508-3509. [PubMed: 16536510]

22. Vernall AJ, Abell AD. Aldrichimica Acta 2003;36:93-105.

23. Published methods for the removal of the ruthenium catalyst are better suited for non-polar compounds. For examples, see a) Maynard HD, Grubbs RH. Tetrahdron Lett 1999;40:4137-4140. b) Haack KL, Ahn YM, Georg GI. Molecular Diversity 2005;9:301-303. [PubMed: 16311806]

24. Cho JH, Kim BM. Org. Lett 2003;5:531-533. [PubMed: 12583761]

25. Shinada T, Hayashi K, Yoshida Y, Ohfune Y. Synlett 2000;10:1506-1508.

26. The literature value of $(+)-2$ was $[\alpha]_{\mathrm{D}}{ }^{20}=+28^{\circ}, c 0.23, \mathrm{CHCl}_{3}$ (see ref. ${ }^{10}$ ) and $[\alpha]_{\mathrm{D}}{ }^{22}=+26.2^{\circ}$, c $0.23, \mathrm{CHCl}_{3}$ (see ref. ${ }^{8}$ ).

27. The literature value of $(-)-2$ was $[\alpha]_{\mathrm{D}}{ }^{20}=-25^{\circ}, c 0.26, \mathrm{CHCl}_{3}$ (see ref. ${ }^{9}$ ). 


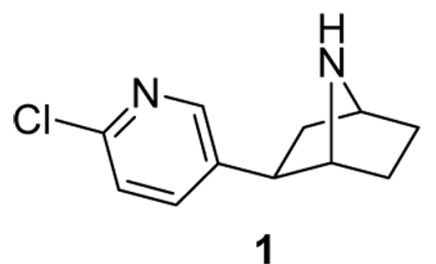

1<smiles>CC(=O)N[C@@H]1CCCN2CCCC[C@H]12</smiles>

(+)-2<smiles>CC(=O)N[C@H]1CCCN2CCCC[C@]12C</smiles>

(-)-2

Figure 1.

Neurologically relevant alkaloids from Epipedobates 


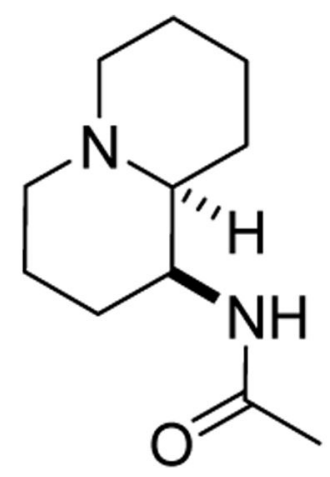

2

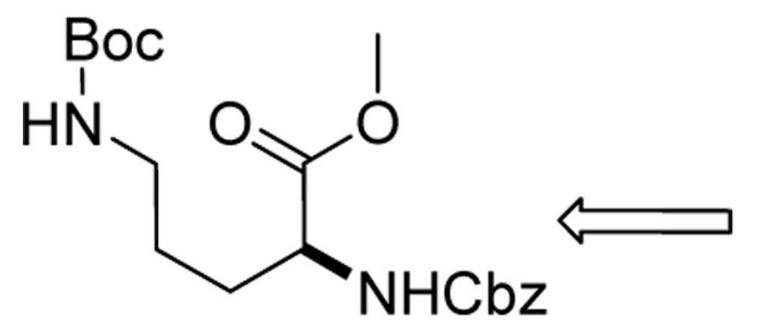

5

Scheme 1.

Retrosynthesis of (+)-Epiquinamide

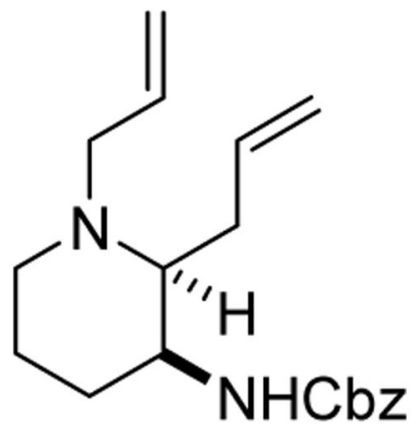

3<smiles>[C]=C</smiles>

$\mathrm{NHBoc}$<smiles>C=CC[C@H](C)[C@@H](C)CCCC</smiles>

$\mathrm{NHCbz}$

4 

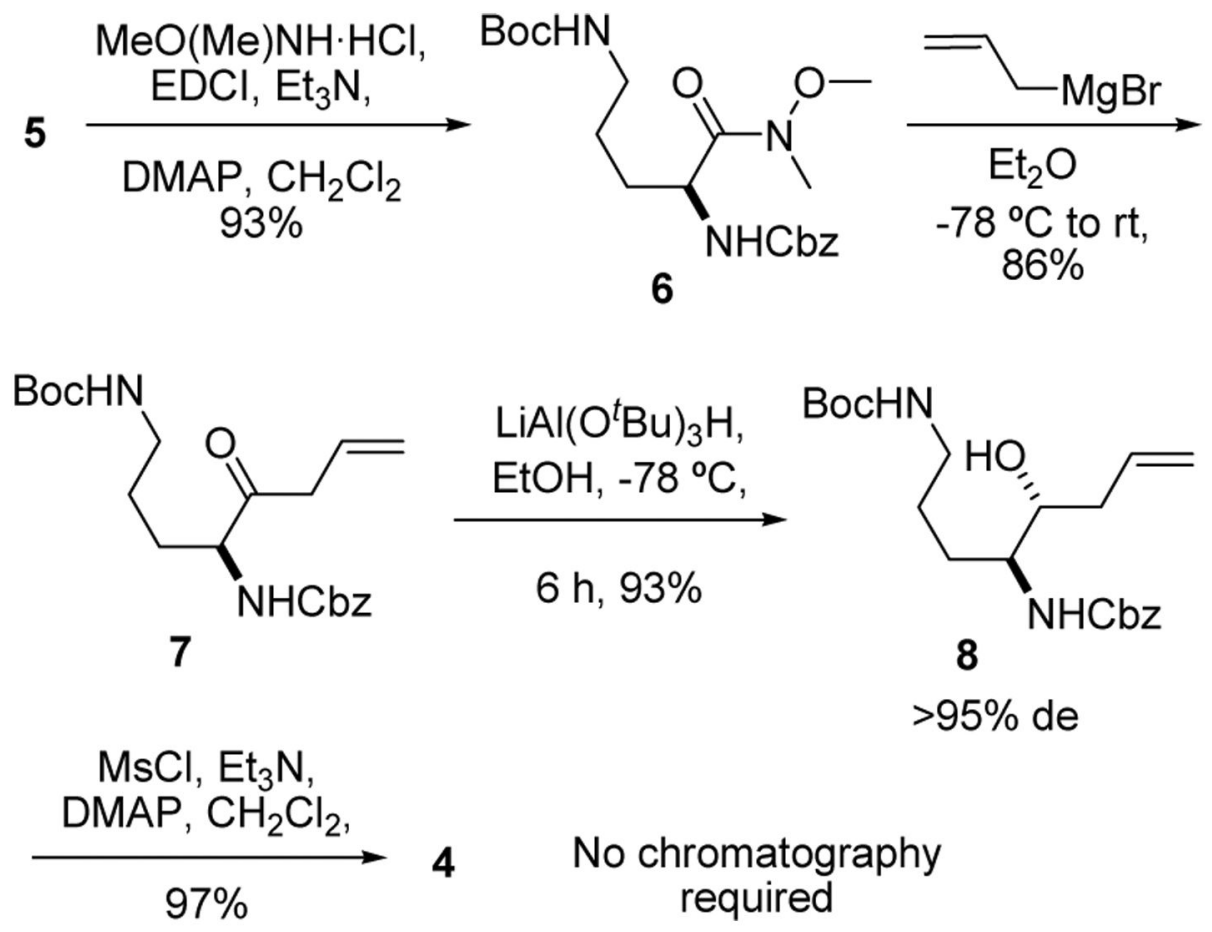

Scheme 2.

Synthesis of Mesylate 4 


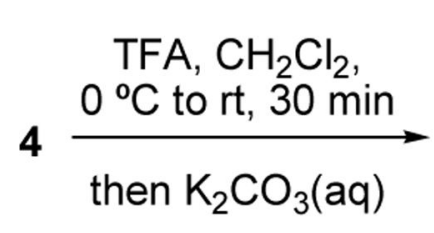<smiles>[R]C(=O)N[C@H]1CCCN(CC=C)[C@@H]1CC=C</smiles><smiles>C=CC[C@H](OC)[C@@H](CCCN)NC(=O)[O-]</smiles>

$\mathrm{K}_{2} \mathrm{CO}_{3}, \mathrm{MeCN}$; then more $\mathrm{K}_{2} \mathrm{CO}_{3}$,<smiles>C=CCBr</smiles>

$73 \%$ over 2 steps

\begin{tabular}{|c|c|}
\hline $\begin{array}{c}\mathrm{H}_{2}, \mathrm{Pd} / \mathrm{C}, \mathrm{Ac}_{2} \mathrm{O}, \\
\text { EtOH, } 2 \mathrm{~d}\end{array}$ & $\begin{array}{c}\text { 1) } \mathrm{H}_{2}, \mathrm{Pd} / \mathrm{C} \text {, EtOH } \\
\text { 2) } \mathrm{Ac}_{2} \mathrm{O} \text {, dioxane, } \\
\mathrm{NaOH}(\mathrm{aq})\end{array}$ \\
\hline $63 \%$ & $87 \%$ \\
\hline
\end{tabular}

Scheme 3.

Synthesis of (+)-Epiquinamide 